\title{
ACCOUNTING FOR GOVERNMENT PERFORMANCE IN THE DEVELOPMENT OF THE NIGER DELTA REGION OF NIGERIA
}

\author{
Hwerien Rosemary Idamoyibo
}

\author{
Department of Accounting, Ignatius Ajuru University of Education, Port \\ Harcourt, Nigeria
}

\begin{abstract}
Purpose - This research accounts for Government performance in the development of the Niger Delta Region of Nigeria. The aim is to investigate the impact of government performance on school enrolment figure and state governments' expenditures on health on the human development index of the region from the period, 1990-2018.

Design/Methodology/Approach - This research adopted the ex-post facto research design and made use of secondary data obtained from the Central Bank of Nigeria Statistical Bulletin and the World Bank Data. The population of the Niger Delta comprises forty million, six hundred and forty-five thousand, two hundred and five $(40,645,205)$ individuals in the region. The data obtained was statistically analysed using multiple linear regression. The Statistical Package for Social Science (SPSS) version 22 was employed for the analysis of the research. Findings - This research found that with the huge revenue generated from crude oil and natural gas by the Nigerian Government from the Niger Delta region, the school enrolment figure and state governments' expenditures on health do not have an impact on human development index on the development of the Niger Delta Region.

Practical Implications - This research recommends that the Ministries of Education and Health, and the State governments must work hard, in order to achieve the Sustainable Development Goals (SDG) in the education and health sectors. The education and health budgetary allocations must be taken seriously and monitored thoroughly so as to ensure every kobo is accounted for. Ensure maximum impact is felt from whatever the government sets aside as the education and health budget and see that it also improves the human capital development of the region. Finally, the State governments should also collaborate with the communities to implement good healthcare system and quality education in the
\end{abstract}


Niger Delta. The essence of this is not just to stop at the budgeting, but also to ensure full and accountable implementation of the health and education budget.

Originality/value - The findings and ideas expressed in this study emanate from an original research endeavour and have contributed to the body of knowledge through accounting for government performance and development of the Niger Delta region of Nigeria, using human development index, school enrolment figure and State governments' expenditure on health as variables.

Keywords Nigeria economy, accounting, government performance, development, niger delta region.

Paper Type Research Paper.

\section{INTRODUCTION}

The Niger Delta region of Nigeria is the southern recess of the country, and also, it is at the shoreline area. The area is well captioned "Ultra Humid (flood) zone because it is at the edge of the Atlantic Ocean. The rise and fall in the ocean affect its topography in various ways. The Niger Delta region is less than seven percent of Nigeria's landmass (Nsirim \& Worlu, 2009). It is the most fragile ecological zone of the entire nation; and it generates eighty percent of gross domestic product, ninetyfive percent of the national budget, and ninety percent of foreign exchange earnings from crude oil to the country's federation account. This has exposed the region and its people to numerous natural and harmful manmade hazards arising from the exploitation and extraction of the region's natural resources by transnational firms (Nsirim \& Worlu, 2009). The Niger Delta environment is richly endowed with crude oil and liquefied natural gas which have made the environment vulnerable to internal and external resentment. It is the resentment that results in national threat and conflict in the region, leading to loss of lives and properties as well as a huge investment in the region (Akubor, 2009).

Government is the office or position of authority that administers the affairs of the state. The exercise of state power to serve the personal interest and the ensuing denial of interests of the generality of the governed constitutes adversity in governance. Governing adversity has affected many development policies in Nigeria resulting in failed development projects, ill-implementation of projects, mass unemployment, poverty, and legitimacy adversity (Akinde, 2009). Accounting is the science of 
recording, classifying, and summarizing in an informative manner and in terms of money, transactions, and events which are, in part at least, of a financial character, and interpreting the results thereof. It is also concerned with the design of the system of records, the preparation of reports based on recorded data, and the interpretation of the reports (Erhirhie, 1995). It is the science or art of identifying, recording, and measuring financial information. In other words, it is a system that brings together information for the purpose of recording and measuring economic events (Ishola, 2012). Accounting is a language that communicates economic information to people who have an interest in an organization (Colin, 2008).

The major resources of the Nigerian economy come from crude oil and natural gas which generate revenue for the country and these natural resources are of the Niger Delta people. The extraction and production of crude oil and natural gas have caused hazard and harm to the life of the people. These have also destroyed the environment of the region through flaring of gas and spillages which cause pollution and contaminations, opening up of forests to loggers, flooding, coaster erosion, earth tremors, land subsidence, and indiscriminate canalization, etc. Most families in the region cannot afford three meals in a day, good healthcare centres or hospitals, and even provide education for their children. The people are deprived the natural resources of their God-given birthright and made to live below a good standard of living among their equals in the country. According to the Niger Delta people, the region is been marginalized as government presence and development are not felt. Against this background, this research is designed to investigate the impact of government performance on school enrolment figures and state governments' expenditures on health in the development of the Niger Delta Region of Nigeria from the period 1990-2018.

\subsection{Research Hypotheses}

The following research hypotheses were formulated and tested:

(i) There is no significant impact between the school enrolment figure and human development index in the Niger-Delta region. 
(ii) There is no significant impact between state governments' expenditures on health and human capital development in the Niger-Delta region.

\section{REVIEW OF RELATED LITERATURE}

\subsection{Development}

Every researcher tries to define development in his/her way, depending on his/her direction or general opinion. Ejuvbekpokpo (2009) argues that development is the progression of individuals in the social order, which encompasses quality education, employment, infrastructure, and good health of individual members in a society, signifying an increase in the standard of living or the worth of the life of a people, showing an outstanding improvement of humanity and the position of production and ingestion. He adds that development is a multi-dimensional practice concerning modifications in structure, approaches, and organizations as well as speeding up of financial growth, the decrease of discrimination, and the abolition of outright poverty. He further argues that the presentday view about development incorporates physical amenities, financial growth as well as other central qualities such as the fairness of prospect, absolute autonomy and rights, sexual category fairness, green safety, and poverty relief, implying that the goal of development is the advancement of the communal and individual well-being of members of society. He further intimates us that the millennium development conference of the year 2000 measured development in the aspects of both quantitative and qualitative objectives. Tamuno (2009) sees development as a general, full, and non-concrete idea, and that there is no agreement about its sense.

The millennium development conference refers to development as measures such as the abolition of poverty and starvation, primary education for every individual, sexual category fairness and women empowerment, low rate of child death, high-level protective healthiness, abolition of sicknesses, ecological sustainability, and the establishment of an environment for world-wide collaboration. Development, according to Edewor (2014), deals with advancing human safety and human liberty; an approach that promotes the fruitfulness of human life, rather than the fruitfulness of the economy in which human beings are living, since 
developing the fruitfulness of the economy does not wholly represent development.

Okoji (2012) views the idea as for when an economic progression of a country is exchangeable with the understanding of the public good so that the general public will have profit from the progress. According to Owolabi \& Owolabi (2009), development is viewed, not as ordinary economic change, but relatively seen as an expansion in all phases of human life, without bargaining the rights of others to succeed. They posit that this description means that development is the same as the norm of social equality and that the perception of developing social equality assumes a strong association to the idea of development as improvement of the social situation relating to the rights of the people in deciding what creates a sincere development of their situation. They further assert that social equality is truly a moral perception because it agrees that it is accurate and reasonable for all nations to take part in the development of the environment. While it is essential for the government to ensure optimal development in the oil host region, it is important that individuals in the oil and gas host communities to have a good understanding of their MOU, objectives, goals, and desires, as well as partake in the process of meeting their needs. This is when their communities or environment will be able to develop adequately.

\subsubsection{Oil and Gas in Nigeria Economy}

Tamuno (2011) notes that the Nigerian government depends on crude oil and liquefied natural gas in revenue generation for economic growth, because the crude oil at the federal level of government has been seen as 'mightier than all'; therefore, the leaders and their groups do not see beyond crude oil and liquefied natural gas. On how Nigerian leaders depend only on oil and liquefied natural gas for revenue generation, he remarks that there is: "trouble between three elephants" termed the $3 \mathrm{Cs}$, communities, companies/corporations, and country, that would step by step tear the stakeholders apart. He reveals that problems began and became graver after the discovery of crude oil in large and commercial quantities in Nigeria, particularly after its first export in 1958. He further states that the resultant crises, conflicts, and confrontations continued to spoil relations between the three stakeholders and from May 1999 to 2011, 
the three stakeholders had unsuccessful exploitation of several opportunities to transform their relationship from conflicts to a peaceful resolution, but crude oil's unstoppable (dictatorial) hold on these companies prevented them from following the path of peace.

Nigeria extremely hinges on multinational and transactional corporations like Chevron, Texaco Nigeria Limited, Shell Petroleum Development Company, Total, Mobil, Agip, Seplat Petroleum Development Company, Platform among others for the extraction of its richly endowed crude oil and liquefied natural gas resources in the Niger Delta region. The Nigerian government has given operational regulators over crude oil prosperity in the Niger Delta region by the Land Use Decree of 1978, the Petroleum Decree of 1969, and the Cap. L5 Laws of the Federation of Nigeria, 2004, and the Section 44 subsection 3 of the 1999 Constitution that it should be managed in the way as approved by the National Assembly of the Nigerian government. From the time when the first delivery of crude oil was made in the year 1958, there has been an increase in oil extraction actions in Nigeria. However, it has led to the detection of plentiful oil and gas fields and then to the expansion of numerous oil and gas stations (Ozobia, 1998).

In the aspect of the Derivation Fight, the earlier conflict between the $3 \mathrm{Cs}$ assumed a form of a major confrontation between the Niger Delta region, otherwise known as South-South Geo-Political Zone on the one hand and the rest of Nigeria on the other side. However, whenever the employees of the multinational oil and gas corporations involved in the operation of oil and gas activities were taken hostage by the angry youth of host communities, or when illegal bunkers and other aggrieved individuals vandalized costly installations, the federal government would deploy military troops to enforce law and order. This infuriated the aggrieved Niger Delta militants who continued to fight the stakeholders. This led to the initiation of the amnesty programme in 2009. Aghalino (2009) refers to the rising review of tax and charges payable by corporations, and advocates change in property rights in Nigeria, to emphasize sustainable development and community participation. Chukwunonyelum (2011) investigated the reactions of individual communities that were denied justice when they sought redress in court due to oil spillage and found out that in most cases, the plaintiffs were dissatisfied as a result of the unfavorable judgment of the courts which were attributed to passivism, lack of environmental awareness, legislative Vol. 28, No. 3 December 2020

(C) Centre for Indonesian Accounting and Management Research Postgraduate Program, Brawijaya University 
provisions, and communication. He recommends that the government should establish an independent court system that would improve the prospects of plaintiffs in courts when suing for environmental contaminations.

Namuyondo (2014) argues that the lack of monitoring and enforcement of legal laws and rules that should serve as a guide to the operation of oil and gas companies in the country contributes to unsustainable exploration activities. She attributes the difficulties experienced to weak institutions, lack of public participation, poor communication, and unskilled labour in the oil and gas industry; absence of significant policies, poor organization structures, and governance system. She recommends that a healthy institution should be established to outline activities in the oil and gas firms that would evade terrible situations that could affect the citizens and the environment.

The crucial need for viable development in Nigeria, especially in the host communities of oil and gas companies was acknowledged by Alabi and Ntukekpo (2012), Namuyondo (2014) and Uzoagu, (2015). This requires all stakeholders, authorities, Multinational Corporations, International Establishments, and Non-Governmental Organizations (NGOs) to play their roles by instituting a variety of policies and laws that will guide how petroleum licensed companies could carry on their activities in a way to improve the sustainability of the economy. Oil and gas exploration in the Niger Delta Region has contributed massively to the government revenue generation (Ayuba, 2012). Tamuno (2011) posits that the oil and gas segment positions itself as the backbone of the Nigerian economy in the understanding of its major role in the economic improvement of the country. Its financial records show over eighty percent (80\%) of Gross Domestic Product (GDP), ninety-five percent (95\%) of the national budget, and ninety percent $(90 \%)$ of foreign exchange earnings of the Federal Government's collectible revenue. Nigeria can now claim that it has over twenty-one (21) billion barrels of confirmed oil reserves and mount as Africa's major oil producer and the world's sixth $\left(6^{\text {th }}\right)$ greatest important exporter of crude oil (Uba, 2015). The increase in oil price throughout the Arab, Israel conflict, and energy difficulties and sadness led to a rise in the oil revenue and oil prosperity for Nigeria and other oilexporting nations. 
Owolabi and Owolabi (2009) opine that the physical advantage from the unforeseen prosperity of oil has not boosted improvement in Nigeria because if it does, its physical advantage will be adored by all and not only by the few that are fortunate in the nation. Worthy life as early Greeks' distinct development is not only the contentment of physical needs, but improvement of global respect for the constitutional rights of all, which is the circumstance for a favorite society that is essential for the people. Nigeria's dependence on crude oil led to some factors such as lack of sustainability in development, lack of food, and extreme bribery and corruption in the nation. The oil treasure does not make the country diversify to non-oil segments; neither is there careful use of the wealth in promoting development for job creation and employment in the social order, nor is it used to improve oil communities somewhat. As there are no further means of survival, individuals in the society decide to indulge in oil theft, vandalization of pipeline, armed/highway robbery, and now kidnapping and internet fraud as options to live above poverty in the nation. This does not only have an emotional impact on the people and the oil and gas expatriates, but also oil production and revenue generation in the nation. The estimation of oil production in the year 2012 was two-point thirty-seven (2.37) million containers per day throughout the first half of the year; this is in contradiction to two-point forty-eight (2.48) million containers per day produced in the first half of the year 2011. Furthermore, the four-point four percent (4.4\%) crude oil production level was a decline, and it was ascribed to troubles in oil production due to circumstances of vandalization of pipeline and oil theft in the oil-producing regions (NNPC, 2012).

\subsubsection{Fiscal matter relating to crude oil}

The oil and gas are a major revenue earner for the Nigeria Government, mainly through participation interest percentages from the joint venture, and production sharing percentages from contracts, taxes, royalties, bonuses, rents, and other payments (Yinka, 2001; and Wright and Gallun, 2008). 


\subsubsection{Participating interest percentage}

According to Yinka (2001), the Nigerian government through the Nigerian National Petroleum Corporation (NNPC) is a major shareholder in all the joint ventures in Nigeria, which deals with exploration and production of crude oil. Accordingly, the government receives the revenue accruing from its percentage of oil produced under the legal arrangements or agreements. The participation interest percentage is a major source of revenue for the Nigerian government, and is quite separate from the amounts received from taxation, royalties, rents, signatures and production bonuses. These amounts are accruing to the government in its capacity as owner or regulator, whilst the participation interest percentage is the government's share as a business partner in the joint venture.

\subsubsection{Production sharing percentage}

In the production sharing contracts, the production is split between the parties, after costs, taxes and other expenses have been paid. Every production sharing contract partner is entitled to its own share of production and to the proceeds of the sale. The government percentage is a source of revenue for the state (Yinka, 2001; Akpan, 2011; and Wright and Gallun, 2008).

\subsubsection{Taxes}

Yinka (2001), Akpan (2011), Wright and Gallun, (2008) posit that taxes are a major means of earning revenue. The petroleum tax is high because of the high economic rents that tend to accrue during periods of high prices. The Nigeria oil taxation is governed by the Petroleum Profits Tax Act 1959, Cap 235, the laws of the Federation of Nigeria, 1990 (PPTA), and the Deep Offshore and Inland Basin Production Sharing Contract Decree 1999. The latter law governs Nigerian production sharing contracts, while natural gas taxation is governed by the laws regulating liquefied natural gas (LNG) and the Associated Gas Framework Agreement (AGFA). 


\subsubsection{Royalties}

Royalties are amounts payable to the owner of a natural resource as compensation for the exploitation of a renewable and irreplaceable natural resource (Yinka 2001; Akpan 2011 and Wright and Gallun, 2008). Royalty payments are like $\$ 200$ million. This is because the companies are anticipating the discovery of large billion-barrel deposits. The production sharing contracts in Nigeria are subject to non-refundable signature bonus payments. In the 1991 bidding, the prospective contractor companies paid bonuses of $\$ 1$ million each. In the production sharing contracts in 1999 which was canceled by the Obasanjo government, the signature bonus was \$20 million (Yinka, 2001).

\subsubsection{Rents}

Yinka (2001) and Wright and Gallun (2008) opine that rents are the amounts paid in exchange for the oil prospecting licenses and oil mining leases granted. Rents paid for non-producing areas are credited 100 percent against petroleum profits tax. Rents for producing leases are credited 85 percent against royalty payments. Other payments such as bank commissions are paid by the oil companies. The government also derives revenue from the industry indirectly through enactments such as the Oil Terminal Dues Act. However, payments made under this law are by the owner of the ship evacuating crude oil and not by the oil-producing company.

\subsubsection{Bonuses}

These are payments made by a company to the government at agreed designated periods. These bonuses are made when the contracts have been signed. Such bonuses are known to be a signature bonus and production bonus which are paid by the contractor to the government when production reaches a mutually agreed level (Wright and Gallun, 2008; and Yinka, 2001). 


\subsubsection{Nigerian National Petroleum Corporation}

The Nigerian National Petroleum Corporation (NNPC) was established in 1977 by an Act of the same name. It was formed as a result of a merger between the Ministry of Petroleum Resources and the Nigerian National Oil Corporation which was established in 1971. The Nigerian National Oil Corporation was established by Decree No. 18 of April 1971 to engage in prospecting for, mining, and marketing of oil and all other activities with the Petroleum Oil Ministry. The Nigerian National Oil Corporation (NNOC) was an offshoot of the Ministry of Mines and Power and from the outset, it had problems centred around the fact of its dependency on the ministry. The initial efforts relating to state participation in Nigeria's oil industry were made through this corporation. Jurisdictional problems between NNOC and the Ministry of Mines and Power led to the creation of NNPC in 1977 through Decree No. 33. The new entity combined the commercial functions of NNOC with the regulatory functions of the Ministry. These later functions were under the Petroleum Inspectorate which was established under part II of the Act as an integral part of the corporation.

The NNPC Act has remained in force in a largely unaltered form since it was first enacted. The affairs of the Corporation are to be conducted by a board of directors. The Act provides that the Board should be chaired by a Minister in the Government of the Federation to be known as the Minister of Petroleum Resources including the Director-general, Federal Ministry of Finance and Economic Development; the Managing Director of the Corporation; and three persons to be appointed by the National Council of Ministers, being persons who by reason of their ability, experience or specialized knowledge of oil industry or of business of professional attainments are capable of making useful contributions to the work of the Corporation. The NNPC's duties include participating in all stages and areas of the upstream and downstream energy sector; carrying out research in connection with petroleum, participating on the Federal Government's behalf in petroleum activities, and engaging in activities to enhance the petroleum industry and to give full effect to the provisions of the Act (Yinka, 2001). 


\subsubsection{Niger Delta Environmental Issues}

Yinka (2001) argues that the environmental issues in the Niger Delta have become important and the oil companies are directly and indirectly involved in the problem. Studies in half of the twentieth century have discovered that crude oil processes have changed the earth in many fundamental ways. The seas are polluted to the detriment of various marine flora and fauna and the desert is expanding, the ozone layers are getting damaged. The climate is being altered, and also there is rapid extinction of plant and animal species. The hydrocarbons have the capacity to pollute the land, seas, and atmosphere greatly. Furthermore, the oil and gas companies are the chief culprits in the depletion of the ozone layer. The contamination caused by the oil and gas companies has deprived the Niger Delta people of their right to farming, fishing, hunting, and cropping, because they do not have any other sources of livelihood and the government is not providing meaningfully for their development.

\subsection{Theoretical Framework}

The theoretical framework underpinning this research is Structuralfunctionalism. Structural-functionalism was led by the scholarly views of American sociologists, Parsons (1951), Davis and Moore (1945), Merton (1957), as well as anthropologists, Adcliffe-Brown (1952), Almond and Powell (1966), etc. Structural-functionalism perceives society as a social structure with functions in which all its parts are likely to function together relatively and cohesively for the benefit of the general public. These theorists stress the functions within the structure that aid the overall survival and growth of the scheme. They posit that, in order to appreciate a political scheme, it is required to appreciate not only its institutional structures, but individual functional components that make up the structure (Almond \& Powell, 1966; and Gauba, 2003). Parsons (1951) established the notion of collectivities of roles that match each other in satisfying functions for the social order. He opines that some roles are bound up in institutions and the societal structures such as gender inequality, educational, economic, and legal concerns that are well-designed for promoting the people effectively and satisfying their functional desires.

The structural-functional framework examines the general public as a scheme made up of a certain arrangement of structures that function 
in a harmonized and mutually supportive way to accomplish the goal of the general public; with the above, stability and harmony can be upheld within the structure (Igwe, 2007). Merton (1957) is of the opinion that, not all components of a contemporary multifaceted people work for the functional unity of the general public. Further, he identifies two categories of functions: latent and manifest, arguing that some institutions and structures may have other functions and some may function or not even function at all. This observation stands because some system structures in the society are functional, while others are not.

Given this realization, Merton introduces the concepts of power and coercion into functionalism and identifies, relating to the facet of 'tension' that may lead to struggle or conflict. He posits that, when identifying and observing the facets of the society that are not functioning, people can give details of the development and tenacity of another course of action. The logical tool provided by the structural-functionalism objectively assesses if, as Merton (1957) observed, not all components of a contemporary multifaceted people work for the functional unity of the general public in the assignment given to the various agencies and their instrumentalities to accomplish the purpose for which they were established at various levels and eras. The success or failure of these agencies infers the tendency of socio-economic and infrastructural stability or instability. Government's failure through the agencies may be obvious in rigid agitations by the people in the region who may feel marginalized, disenchanted, and exploited. The outcome of this may be conflicts, protests, and agitations that may threaten the peace and security of the region and the nation in general.

\subsection{Empirical Review}

Okereka (2015) carried out a research on the Contingency Theory and Government's Critical Initiatives in Resolving the Developmental Problems in the Niger Delta Region of Nigeria. The research examined the import and the philosophy of the contingency theory as well as evaluating these contingent initiatives to ascertaining whether they have expressed their utility in meeting its objectives of serving as a development approach to resolving the problems inherent in the region. The research adopts the descriptive and analytic approach in arriving at the fact that contingency 
theory is still contemporary, but requires a detailed understanding of the situation under which such decisions must be taken. The researcher concluded that there is a setting up of various interventional agencies, but these agencies have not adequately addressed the developmental needs of the region, because the leaders did not perfectly understand the situation or the environment.

Aghalino (2012) Carried out a Study on Brief but Revolutionary: Yar' Adua and the Sustainable Development of the Niger Delta, Nigeria. The study tried to explain and dissect the administration's approach to the resolution of the crisis in the region. The researcher used primary and secondary sources of data. The findings reveal that the research is done against the background of the initial effort to redress the crisis. The researcher argues that the hallmark of Yar'Adua's initiative is the affirmation of amnesty to the militants in the area. It is contended that for permanent peace to remain in the zone, the current administration must go further than the Amnesty and reintegrate the militants into the majority of society by winning over their attention and making them be participants in the oil industry.

Njoku and Adeyemi (2013) investigate the disparities in Public and Private Pre-Primary and Primary Schools' Enrolments, Classrooms, and Teachers in Nigeria: Implications for Access and Educational Management. The objective of the research is to examine the differences in enrolments, classrooms, and teachers between public and private preprimary and primary schools in Nigeria as the basis for argument on admission and management of education. The research makes use of secondary data obtained from the Basic and Senior Secondary Education Statistics in Nigeria, 2004 and 2005, of the Federal Ministry of Education (2006). The research employs descriptive statistics and a latitudinal approach using 2005 as the standard year and it cuts across all the 36 states of the federation including the Federal Capital Territory (FCT), Abuja. The findings reveal that by 2005 , the number of unenrolled school-age children (6-12 years) was 2,448,588, while the gross unenrolled (6-11 years) was $3,516,476$. The worrying and very ugly situation, according to them, is that the unenrolled rate of school-age children could be as a result of issues beyond the control of parents such as poor environment and schools being too far away from the children's homes, which in turn, calls for proper school planning. 
Aluko and Aluko (2012) study Human Capital Development: Nigeria's Greatest Challenge. The aim of the study is to examine arguments for why highly planned and developed human capital will be the source of comparative advantage in the twenty-first century global economy. The study makes use of analytical approach and concludes that there is a great challenge in human capital development to the extent that government's failure to solve the challenge would eventually result in a society full of a very reduced quality of life stemming from a huge difference between a minority that does have, and a majority that does not have, which will weaken the basis of civil society and the nation's democracy. According to them, this challenge can be resolved by building the skills of youth and incumbent workers and stopping the leakage of people out of the labour market. They argue further that for education to contribute meaningfully to development, it must be of high quality to meet the skill-demand requirements of the economy. They posit that education is highly contributory and also essential to advance the production capacity of any country, particularly Nigeria.

For Nigeria to meet the human capital development challenges of the 21 st century and beyond, they advance the idea that the differences and mistakes of the education system need to be immediately settled as a requirement to restoring and moving the system to leverage general development. They also remark that education policy formulation, planning, implementation, funding, and quality assurance should as much as possible involve all key stakeholders including the private sector, the communities, and the civil society. They recommend that planned strategies by the government in the education and health segments should be fully carried out with reports provided of progress made at each stage. Moreover, the government should upsurge not just the amount of expenditure made on education and health sectors, but also the percentage of its total expenditure given to these sectors. The ten (10) percent benchmark offered by the nationwide plan should be implemented. They conclude that it is through carefully planned policies that Nigeria can begin to fully benefit from human capital development in such a way that will improve economic performance and development.

Jack-Akhigbe (2013) conducts a study on The State and Development Interventions in the Niger Delta Region of Nigeria. The research examines the forces that have made state interventions unlikely 
to achieve positive results in overcoming the deepening development crisis in the region. It employs primary and secondary sources of data collection. The finding reveals that state attempts have been foundered by the same forces that precipitated underdevelopment in the region. The research locates them within the locus of the character of the Nigerian State and those at the head of it at different levels.

Higgins (2009) studies Regional inequality and the Niger Delta. The research explores one of the Government of Nigeria's (GoN) responses to the marginalization of the Niger Delta, the Niger Delta Development Commission (NDDC) in the context of the worsening development condition in the Niger Delta. The study reveals that poverty and inequality in Nigeria have strong regional attention, resulting in significant levels of regional difference. It ascertains that the Niger Delta is a region that has been somewhat marginalized from Nigeria's national development, despite being the region that generates the country's oil wealth and that the GoN's policy response to this marginalization and relative underdevelopment is the NDDC, which was established in 2000.

It further states that the development of the Niger Delta from the time the NDDC was established shows that poverty reduction and improvement have been slow, particularly given the Niger Delta's considerable natural resource endowments and additional federal government resources. It points out that it is problematic to assess the effectiveness of the NDDC, the extent to which it has contributed, or failed to contribute to poverty reduction in the Niger Delta. It concludes that apparently, natural resource endowments do not essentially translate into welfare gains for the communities. In addition, it states that national-level government, its political and financial commitment to address regional differences may not be sufficient and may be disallowed because of the 'top-down' nature of the approach and is ineffective if reliant on institutionally weak states and local governments.

Efebeh (2017) looks at The Role of Interventionist Agencies in Addressing Poverty and Development Challenges in the Niger Delta Region of Nigeria. The aim is to examine the developmental activities and efforts of various governmental agencies established in the wake of environmental degradation, infrastructural decay, and poverty in the Niger Delta Region. Given the rate of poverty, unemployment, and the healthrelated problems occasioned by the exploration and exploitation of oil, the study notes that the performance of interventionist governmental agencies Vol. 28, No. 3 December 2020

(C) Centre for Indonesian Accounting and Management Research Postgraduate Program, Brawijaya University 
has become very irrelevant in addressing the dilemma of the people of the region. The research makes use of the historical method of data collection with reliance on secondary sources of gathering information and notes that as a result of the lack of political will and endemic corruption in the system, all the interventionist agencies have failed woefully to meet the purpose for which they were set up. It however recommends that honest political will devoid of sentiments and corruption will go a long way in developing the region and as a result alleviate poverty, rather than the mere emphasis on the establishment of interventionist institutions.

Otega, Danni, and BadariahHj (2015) study Nigerian Niger Delta Community Participation: Catalyst for Sustainable Human Development. The study examines community participation as a catalyst to foster sustainable community and human development in the region. An in-depth interview was conducted with the key informants. The qualitative data was obtained and analyzed using the Nvivo 10 software. The findings reveal that issues such as community involvement in decision-making, awareness of government intervention programmes, adequate consultation, and collaboration are the catalyst for community participation. The research, therefore, concludes that there is a need for government and development agencies to comprehend the needs and ambitions of the community in policy formulation and implementation of developmental goals.

Tae and Shannon (2013) carry out a research on Government Health Expenditure and Public Health Outcomes: A Comparative Study among 17 Countries and Implications for US Health Care Reform. The objective of the study is to analyze the relationship between public health expenditure and national health outcomes among developed countries. The data collected is from 17 OECD countries between 1973 and 2000. Two public health outcome indicators, infant mortality rate, and life expectancy at birth are used as dependent variables. To analyze cross-country panel data, the study used a mixed-effect model. A statistically significant relationship was established between government health expenditure and public health outcomes. The findings reveal a negative connection between government health expenditure and infant mortality rate, and a positive connection between government health expenditure and life expectancy at birth. The results suggest that higher government spending 
on medical goods and services can be shown to provide better overall health results for individuals.

Akubor (2009) conducts a study on Blessing or Curse: The Nigeria Maritime Resources, Misuse and Implementation for Economic Development in the Niger Delta. The aim is to examine the wealth of the country, vis-à-vis the activities of the saboteurs, which led to the poverty state of the people, its implication for the nation, and possible way out. The study concludes that the Government should be able to tailor the revenue allocation formula in such a way that it will be to the advantage of the people of the area, as this will to a large extent help in curbing feudalizations and other related crimes in the area. Furthermore, considering the terrain of the region, it recommends that government should try as much as possible to work out programmes that will improve the lives of many people. It notes that this has become even more necessary considering the fact that the people no longer have good land for farming and other economic activities, and that even the few they have can no more produce much due to pollution arising from the activities of explorers. It recommends that government, as a way of reconciliation, should call the various groups in the region to a round table talk, instead of ignoring or employing military force on them. It asserts that this is one aspect where the present administration has scored high points, but it can do better.

Akinde (2009) looks at The Crises of Governance and the Realization of the Millennium Development Goals in Nigeria. The study employs the theoretical framework of dependency, rentier state, and prebendalism, and contends that the nature of the Nigerian state which has always thwarted efforts towards development through bad governance characterized by corruption, may also act as an obstacle towards the realization of the millennium goals. The study advocates a change in the character of the state, through exemplary leadership, socio-cultural value reorientation, effective democratization processes whose features include sound legitimation footing, socio-economic empowerment, application of principles of rule of law, transparency, and accountability amongst others, to enhance the achievement of millennium development goals.

Nsiri-Worlu (2009) conducts a study on Poverty and the Environment in the Niger Delta Region of Nigeria. The study intends to establish the social link between poverty and the environment of the Niger Delta people of Nigeria and makes a recommendation for the way forward.

\author{
Vol. 28, No. 3 December 2020 \\ (C) Centre for Indonesian Accounting and Management Research \\ Postgraduate Program, Brawijaya University
}


The study employs a historical materialism theoretical framework. The study perceives that the environment and the people of the Niger Delta are endangered and recommends that, to disintegrate the vicious cycle of poverty and environment, the government should be able to formulate and implement policies and strategies that will bring about poverty reduction; proper use and management of the environment through the proper harnessing of its natural resources; and environmental education to every person which will directly result to the optimum good life for all. Also, it observes that the nation will be on the path of attaining the goals contained in the agenda of the millennium development goals of the united nations when social inequality among people and nations have reduced and the environment is religiously handled and managed by all.

Ejuvbekpokpo (2009) looks at Sustainable Development through Poverty Alleviation/Eradication in Nigeria. The study examines the concept of poverty and sustainable development, the dimensions of poverty in Nigeria, poverty eradication programmes put in place by successive governments in Nigeria, elements contributing to the escalation of poverty, conclusion, and recommendations for poverty eradication strategies. The study makes use of secondary sources of data collection from qualitative materials. The study concludes that the issues of poverty eradication are multi-dimensional. It highlights the factors that are incidental to the increasing uncontrollable levels of poverty in Nigeria, which include over-reliance on oil as the only sources of the country's income without bearing in mind price volatility in the world market, lack of productive agricultural focus, lack of programmes for empowering and creating employment opportunities for the crowded population, increasing waves of corruption and the offensive behaviour of public servants. It suggests that a multiparty approach which must comprise the state and local governance as well as private institutions and other folks concerned with privately determined individuals is required to fight the monster.

\section{METHODS}

The research adopts the ex-post facto research design and employs secondary sources of data in line with the objective of the study. The study covers the nine (9) states of the Niger Delta Region; Delta, Bayelsa, Edo, 
Ondo, Abia, Akwa Ibom, Imo, Rivers, and the Cross River States. In order to get the estimated population of the Niger Delta people for the year 2018, the 2006 National population census figures of the people were used with a determinant population growth rate. The National Population Commission, drawing from the 2006 census, notes that there was an increase of $2.67 \%$ for twelve (12) years, up to the year 2018, in Nigeria's population. Since Nigeria's population increases by $2.6 \%$ rate, to estimate the population figure of the people of the Niger Delta, the researcher multiplied $2.6 \%$ by 12 years, and added the resulting figure to the 2006 population figure to determine the current population of the people in the Niger Delta Region.

The population of the Niger Delta Region of Nigeria comprises forty million, six hundred and forty-five thousand, two hundred and five $(40,645,205)$ individuals (National Bureau of Statistics, Nigeria, 2017; Countrymeters, 2017). The researcher aggregates the data for state governments' expenditure on health, school enrolment figure, and human development index and averaged it by the number of states in the Niger Delta region per annum. It is averaged so that the final data can be obtained for the analysis. The data obtained is statistically analyzed using multiple linear regression. The Statistical Package for Social Science (SPSS) version 22 is employed in this study. However, multiple linear regressions are used to test the hypotheses of the research to ascertain the impact of government performance on the development in the Niger Delta Region.

\title{
3.1. Models Specification
}

For the purpose of this research, the model of Uadiale and Fagbemi (2012) is adopted and modified.

$\mathrm{b}_{1}-\mathrm{b}_{2}>0$

$\mathrm{b}_{1}-\mathrm{b}_{2}<0$

$\mathrm{HDI}_{\mathrm{t}}=\mathrm{f}\left(\mathrm{SEF}_{\mathrm{t}}, \mathrm{SGEH}_{\mathrm{t}}\right)$

These are further stated in econometric forms below:

$\mathrm{HDI}_{\mathrm{t}}=\mathrm{b}_{0}+\mathrm{b}_{2} \mathrm{SEF}_{\mathrm{t}}+\mathrm{b}_{3} \mathrm{SGEH}_{\mathrm{t}}+\mathrm{U}_{\mathrm{i}}$

Where:

HDI $_{\mathbf{t}}=$ Human Development Index is an index used to measure human capital development in any economy. It is the standard measure of economic development. Therefore, the research used

\author{
Vol. 28, No. 3 December 2020 \\ (C) Centre for Indonesian Accounting and Management Research \\ Postgraduate Program, Brawijaya University
}


the HDI to capture the development in the Niger - Delta region over the period of the research.

$\mathbf{S E F}_{\mathbf{t}}=$ School enrolment figure $(\mathrm{SEF})$ is another key and important index for the measurement of human development index. The SEF tells the number of educated versus the non-educated and this is believed to have correlation with human development indices.

SGEH $_{\mathbf{t}}=$ State governments' expenditure on health becomes important in this research because it also influences the human development index of the host communities.

$\mathbf{U}_{\mathbf{i}}$ is the Stochastic Term that covers all the other variables that affect HDI, SGEH and SEF, but were not included in the model.

\subsubsection{Apriori Expectation}

The apriori expectation is that the predictors variable SGEH and SEF will have a positive and significant impact on the criterion variable HDI of the Niger Delta Region.

\section{RESULTS}

Table 4.1 reveals changes in the averages of the variables over the period of the investigation. The table shows that HDI, on average, has been fluctuating by falling and rising over time in the Niger Delta region. The figures show that the HDI falls from an average of 0.389 percent (1990) to 0.572 percent (1995) over a period of 6 years and rises from 0.803 percent (1996) to 0.793 percent (1997). It begins to fall from (1998) to (1999) and rises with 0.757 percent (2000) and fluctuates from (2001) to (2008) and finally rises from 0.799 percent (2009), 0.767 percent (2010), 0.674 percent (2011), 0.673 percent (2012), with a decline from (2013) downward to (2018). Furthermore, the table reveals that the SEF falls from 223 thousand (1990), 344 thousand (1991) to 5432 thousand (1992) and begins to rise from 65990 thousand (1993) onward to 554328.1 thousand (2018) over the period. The table also shows that SGEH rises from 63.01 million (1990), 163.78 million (1991), 311.83 million (1992), 428.36 
million (1993), 552.77 million (1994), 677.18 million (1995) to 801.59 million (1996) and it falls to 926 million (1997), and finally, begins to rise onward from 1050.41 million (1998) to 3538.61 million (2018) over the period.

The result in table 4.2 indicates that the mean statistics of state governments' expenditure on health is 1796.8700 and the school enrolment figure is 270983.5000 , while the human development index is .5584. The result shows that the impact of government on human capital development is very low and the implication is that, the funds provided by the government for state government expenditure on health and school enrolment were not properly implemented and utilized.

The result of the regression analysis shows that an F-value of 0.294 was obtained from the analysis of variance of regression model at $\mathrm{P}=0.294$, showing the existence of significant collective impact of independent variables on the dependent variable. This is also an indication of a goodfit of data to the linear regression model. The relationship is judged significant at a $\mathrm{P}<0.05$ level of significance. The $\mathrm{t}$ - values that were obtained from the analysis show how the dependent variable relates to the independent variables on an individual basis.

Decision: Based on the results, the coefficient of determination $\left(\mathrm{R}^{2}\right)$ which measures the goodness of fit of the model indicates that $2 \%$ of the variations observed in the dependent variable were explained by the independent variables. This was moderated by the Adjusted R-square of $5 \%$. The significant t-value was obtained from school enrolment figure and state governments' expenditures on health at $(\mathrm{t}=0.130, \mathrm{P}=0.09>0.05)$, and $(t=0.103, P=0.09>0.05)$. Since the coefficient estimate of HDI is negative and $\mathrm{P}>0.05$, the null hypothesis is accepted with the conclusion that there is no significant impact between school enrolment figures and state governments' expenditures on health on the Human Development Index.

\title{
5. DISCUSSION OF FINDINGS
}

The school enrolment figures in the region have a negative and insignificant impact on the human capital development of the region. The state governments' expenditure on health in the region has a negative and insignificant impact on the human development index in the region. The results of this research were supported by Efebeh (2017), Okereka (2015),

\author{
Vol. 28, No. 3 December 2020 \\ (C) Centre for Indonesian Accounting and Management Research \\ Postgraduate Program, Brawijaya University
}


Otega, Danni and BadariahHj (2015); Tae and Shannon (2013), Njoku and Adeyemi (2013), Ejuvbekpokpo (2009), and Nsiri-Worlu (2009) that government performance does not have significant impact on the development of the Niger Delta Region of Nigeria.

\section{CONCLUSION AND RECOMMENDATION}

The research established accounting for government performance and development of the Niger Delta Region of Nigeria using multiple linear regression to test the hypotheses in the research. The result shows that there were no significant relationships between the criterion variable and predictor variables. The research concludes that with the huge revenue generated from crude oil and natural gas by the Nigerian Government in the Niger Delta region, there is no significant impact between school enrolment figures and state governments' expenditures on health on the human development index in the development of the Niger Delta region.

The research recommends that the Ministry of Education and other educational bodies must work together in the region to boost school enrolment. This has been shown to have a negative and insignificant impact on human capital development and therefore, is supposed to become a nexus for more benefits that will accrue to the region through human capital development. The Ministries of education, health, and the State governments must work hard, in order to achieve the Sustainable Development Goals (SDG) in the education and health sectors. The education and health budgetary allocations must be taken seriously and monitored thoroughly so as to ensure every kobo is accounted for. The maximum impact must be felt from whatever the government sets aside as the education and health budget and this should be seen to also improve the human capital development in the region. Finally, the State governments should also collaborate with the communities to implement a good healthcare system and quality education in the Niger Delta. The essence of this is not just to stop at the budgeting, but also to ensure full and accountable implementation of the health and education budget. 


\section{REFERENCES}

Aghalino, S. O (2009). Gas Flaring Environment Pollution and Abatement Measures in Nigeria, Journal of Sustainable Development in Africa, 11(4).

Aghalino, S. O (2012). Brief but Revolutionary: Yar' Adua and the Sustainable Development of the Niger Delta, Nigeria. Global Advanced Research Journal of History, Political Science and International Relations, 1(6), 144-151.

Alabi, F.O., \& Ntukekpo, S. S. (2012). Oil Companies and Corporate Social Responsibility in Nigeria: An Empirical Assessment of Chevron's Community Development Projects in the Niger Delta, British Journal of Arts and Social Sciences, 4(2), 361-374.

Aluko, A. Y., \& Aluko, O. (2012), Human Capital Development: Nigeria's Greatest Challenge. Journal of Management Policy and Practice, 13(1), 162-177.

Akpan, E. F (2011). Fundamentals of Oil and Gas Accounting. Jos: Massalaci Juma'a, Larigraphic Printers.

Akinde, S. L (2009). The Crisis of Governance and the Realization of the Millenium Development Goals in Nigeria. Society and Development. An Interdisciplinary Journal of the Nigerian Sociological Society, 1(1\&2), 381-390.

Akubor, E. O (2009). Blessing or Curse: The Nigeria Maritime Resources, Misuse and Implementation for Economic Development in the Niger Delta. Society and Development. An Interdisciplinary Journal of the Nigerian Sociological Society, 1(1\&2), 435-443.

Almond, G., \& Powell, G. (1966) Comparative politics: A developmental approach. Boston: Little Brown.

Ayuba, A. K (2012). Environmental Impacts of Oil Exploration and Exploitation in the Niger Delta of Nigeria. Global Journal of Science 
Frontier Research Environmental and Earth Sciences: Global Journal, 12(3), 18-28.

Chukwunonyelum, O. O (2011). The Courts and the Implementation of Environmental Laws and Personal Rights in Respect of Oil Exploration and Exploitation in Nigeria. Journal of Environmental Management and Safety, 2(3).

Colin, D (2008), Management and Cost Accounting, ( $7^{\text {th }}$ ed.), London: Cengage Learning.

Countrymeters, (2017), Nigeria Population Retrieved from http://countrymeters.info/en/Nigeria\# population2017

National Bureau of Statistics, Nigeria (2017). 2006 National Population Census Retrieved from http://nigeria.opendataforafrica.org/xspplpb/nigeria-census

Davis, K., \& Moore, W. E. (1945), Some Principles of Stratification; American Sociological Review, 10(2).

Efebeh, E. V (2017). The Role of Interventionist Agencies in Addressing Poverty and Development Challenges in the Niger Delta Region of Nigeria. Nigerian Journal of Management Sciences 6(1), 385-392.

Ejuvobekpokpo, A. S (2009). Sustainable Development through Poverty Alleviation/ Eradication in Nigeria, Society and Development: $A n$ Interdisciplinary Journal of the Nigerian Sociological Society, 1(2), 391402.

Erhirhie, U. O. W (1995). Accounting Theory and Practice, Benin: New Era Publications.

Gauba, O.P. (2007). An introduction to political theory, Delhi: Macmillan Indian Ltd. 
Higgins, K (2009). Regional inequality and the Niger Delta. Policy Brief No 5. Prepared for the World Development Report. Overseas Development Institute.

Ishola, K.A (2012). Foundation in Accounting for Tertiary Institutions \{ In Compliance with the Requirements of International Financial Reporting Standards (IFRS)\}, Ilorin: Lavgark Publications.

Igwe, O (2007). Politics and Globe Dictionary, New Edition, Enugu: Keny and Brothers Enterprises.

Jack-Akhigbe, O. P (2013). The State and Development Interventions in the Niger Delta Region of Nigeria. International Journal of Humanities and Social Science 3(10), 255-263.

Njoku, A. C., \& Adeyemi, A. M. (2013), Disparities in Public and Private Pre-Primary and Primary Schools' Enrolments, Classrooms and Teachers in Nigeria: Implications for Access and Educational Management. International journal of development and management review (INJODEMAR) 8(1), $246-255$.

Nsirim-Worlu, H. G (2009). Poverty and Environmental in the Niger Delta Region of Nigeria. Society and Development. An Interdisciplinary Journal of the Nigerian Sociological Society, 1(1\&2), 349-356.

Merton, R (1957) Social theory and social structure: Revised and enlarged, London: The Free Press of Glencoe.

Okereka, O. P (2015). The Contingency Theory and Government's Critical Initiatives in Resolving the Developmental Problems in the Niger Delta Region of Nigeria. Public Policy and Administration Research, 5(9), 106110.

Okoji, O. O (2012). Multinational Oil Corporations Corporate Integrity Ethics and Sustainable Development in Niger Delta, Nigeria. Journal of Sustainable Development, 5 (10), 114-121. 
Otega, O., Danni, S., \& BadariahHj, D. (2015). Nigerian Niger Delta Community Participation: Catalyst for Sustainable Human Development. International Journal of Humanities and Social Science Vol. 5, No. 9(1), 230-238.

Owolabi, K. A., \& Owolabi, O. (2009). Corporate Social Responsibility and the Crisis of Development in Africa. Journal of Sustainable Development in Africa, 10(4).

Owolabi, A (n.d.). Corporate Social Responsibility Disclosures of Nigerian Companies from 2006-2010. Lagos: Pan-African University Press. Retrieved from aowolabi@lbs.edu .ng;owolabiakintola@yahoo.com.

Ozobia, N. V (1998). Engineering Challenges in the Nigerian Maritime Industry. Third Engineering Distinguished Lecture. Faculty of Engineering, University of Lagos.

Parsons, T (1951). The social system, London: Routledge.

Radcliffe-Brown, A.R. (1950). Introduction; in A.R. Radcliffe-Brown \& W.C. Daryll-Ford (Eds.). African systems of kinship and marriage, London: Oxford University Press.

Tamuno, N. T (2011). Oil Wars in the Niger Delta; 1849-2009, Ibadan: Stirling -Horden Publishers Ltd.

Tae, K. K., \& Shannon, R. L. M. (2013), Government Health Expenditure and Public Health Outcomes: A Comparative Study among 17 Countries and Implications for US Health Care Reform. American International Journal of Contemporary Research, 3(9), 8-13.

Uba, C. B (2015). An Appraisal of Corporate Social Responsibility of Oil and Gas Industry in Nigeria for Sustainable Development, (Unpublished Dissertation) University of Nigeria, Enugu Campus, Enugu, Nigeria.

Uzoagu, F (2015). Corporate Social Responsibility of Shell Petroleum Development Company (SPDC) and Nigeria Agip Oil Company (NAOC) 
for Socio-Economic Sustainable Development of Host Communities in Rivers State, Journal of Economics and Sustainable Development, 6(3).

World Bank, (2018). World Development Indicators, Data on CD-ROM. World Bank: Washington, D.C.

Wright, J. W., \& Gallun, A. R (2008). Fundamentals of Oil and Gas Accounting. ( $5^{\text {th }}$ ed.) Oklahoma: South Sheridan, PennWell Corporation.

Yinka, O (2001). Oil and Gas Law in Nigeria. Malthouse Law Books Simplified Series. Ikeja: Lagos, Malthouse Press Limited.

\section{Table 4.1: Represent the everages of SGEH, SEF AND HDI.}

$\begin{array}{llll}\text { Year } & \text { SGEH (A'million) } & \text { SEF (thousand) } & \text { HDI \% } \\ 1990 & 63.01 & 223 & 0.389 \\ 1991 & 163.78 & 344 & 0.361 \\ 1992 & 311.83 & 5432 & 0.621 \\ 1993 & 428.36 & 65990 & 0.659 \\ 1994 & 552.77 & 68594.5 & 0.611 \\ 1995 & 677.18 & 88833.4 & 0.572 \\ 1996 & 801.59 & 109072.3 & 0.803 \\ 1997 & 926 & 129311.2 & 0.793 \\ 1998 & 1050.41 & 149550.1 & 0.597 \\ 1999 & 1174.82 & 169789 & 0.38 \\ 2000 & 1299.23 & 190027.9 & 0.757 \\ 2001 & 1423.64 & 210266.8 & 0.406 \\ 2002 & 1548.05 & 230505.7 & 0.369 \\ 2003 & 1672.46 & 250744.6 & 0.479 \\ 2004 & 1796.87 & 270983.5 & 0.676 \\ 2005 & 1921.28 & 291222.4 & 0.668 \\ 2006 & 2045.69 & 311461.3 & 0.618 \\ 2007 & 2170.1 & 331700.2 & 0.56 \\ 2008 & 2294.51 & 351939.1 & 0.424 \\ 2009 & 2418.92 & 372178 & 0.799 \\ 2010 & 2543.33 & 392416.9 & 0.767 \\ 2011 & 2667.74 & 412655.8 & 0.674\end{array}$

Vol. 28, No. 3 December 2020

(C) Centre for Indonesian Accounting and Management Research Postgraduate Program, Brawijaya University 


$\begin{array}{llll}2012 & 2792.15 & 432894.7 & 0.673 \\ 2013 & 2916.56 & 453133.6 & 0.353 \\ 2014 & 3040.97 & 473372.5 & 0.394 \\ 2015 & 3165.38 & 493611.4 & 0.369 \\ 2016 & 3289.79 & 513850.3 & 0.42 \\ 2017 & 3414.2 & 534089.2 & 0.593 \\ 2018 & 3538.61 & 554328.1 & 0.409\end{array}$

Secondary source: Author's Average Computations, 2019.

Primary sources: CBN statistical bulletin and World Bank data, 19902018.

Table 4.2: Descriptive Statistics of the impact of government performance on the development of the Niger Delta region with respect to the mean.

\begin{tabular}{|c|c|c|c|c|c|c|c|c|c|}
\hline & $\mathrm{N}$ & \multirow{2}{*}{$\begin{array}{c}\text { Minimu } \\
\mathrm{m}\end{array}$} & \multirow{2}{*}{$\begin{array}{c}\text { Maxi } \\
\text { mum } \\
\text { Statis } \\
\text { tic }\end{array}$} & \multirow{2}{*}{$\begin{array}{c}\text { Mean } \\
\text { Statisti } \\
\text { c }\end{array}$} & \multirow{2}{*}{$\begin{array}{c}\text { Std. } \\
\text { Deviation } \\
\text { Statistic }\end{array}$} & \multicolumn{2}{|c|}{ Skewness } & \multicolumn{2}{|c|}{ Kurtosis } \\
\hline & Statistic & & & & & $\begin{array}{c}\text { Statisti } \\
\mathrm{c}\end{array}$ & $\begin{array}{l}\text { Std. } \\
\text { Error }\end{array}$ & $\begin{array}{c}\text { Statisti } \\
\mathrm{c}\end{array}$ & $\begin{array}{l}\text { Std. } \\
\text { Error }\end{array}$ \\
\hline SGEH & 29 & 63.01 & $\begin{array}{r}3538 . \\
61\end{array}$ & $\begin{array}{r}1796.8 \\
700\end{array}$ & $\begin{array}{r}1059.319 \\
26\end{array}$ & .000 & .434 & -1.200 & .845 \\
\hline SEF & 29 & 223.00 & $\begin{array}{r}5543 \\
28.10\end{array}$ & $\begin{array}{r}270983 \\
.5000\end{array}$ & $\begin{array}{r}172435.8 \\
2906\end{array}$ & -.005 & .434 & -1.190 & .845 \\
\hline HDI & 29 & .35 & .80 & .5584 & .15362 & .092 & .434 & -1.408 & .845 \\
\hline $\begin{array}{l}\text { Valid N } \\
\text { (listwise) }\end{array}$ & 29 & & & & & & & & \\
\hline
\end{tabular}

Source: Author's computation using SPSS version 22.

Table 4.3. Regression Results of the variables under study

\begin{tabular}{|l|c|c|l|}
\multicolumn{4}{c|}{ Variables Entered/Removed $^{\mathrm{a}}$} \\
Model & $\begin{array}{c}\text { Variables } \\
\text { Entered }\end{array}$ & $\begin{array}{c}\text { Variables } \\
\text { Removed }\end{array}$ & Method \\
\hline 1 & SGHE, SEF $^{\mathrm{b}}$ & & Enter \\
\hline
\end{tabular}

a. Dependent Variable: HDI

b. All requested variables entered. 
Model Summary

\begin{tabular}{|l|l|r|r|r|}
\hline Model & $\mathrm{R}$ & R Square & $\begin{array}{c}\text { Adjusted R } \\
\text { Square }\end{array}$ & $\begin{array}{c}\text { Std. Error of } \\
\text { the Estimate }\end{array}$ \\
\hline 1 & $.149^{\mathrm{a}}$ & .022 & -.053 & .15765 \\
\hline
\end{tabular}

a. Predictors: (Constant), SGEH, SEF

ANOVA $^{\mathrm{a}}$

\begin{tabular}{|c|c|c|c|c|c|c|}
\hline & & $\begin{array}{l}\text { Sum of } \\
\text { Squares }\end{array}$ & Df & $\begin{array}{l}\text { Mean } \\
\text { Square }\end{array}$ & $\mathrm{F}$ & Sig. \\
\hline \multirow[t]{3}{*}{1} & Regression & .015 & 2 & \multirow{3}{*}{$\begin{array}{r}.007 \\
.025\end{array}$} & \multirow[t]{3}{*}{.294} & \multirow[t]{3}{*}{$.748^{\mathrm{b}}$} \\
\hline & Residual & .646 & 26 & & & \\
\hline & Total & .661 & 28 & & & \\
\hline
\end{tabular}

a. Dependent Variable: HDI

b. Predictors: (Constant), SGEH, SEF

\section{Coefficients $^{\mathbf{a}}$}

\begin{tabular}{|c|c|c|c|c|c|}
\hline \multirow[b]{2}{*}{ Model } & \multicolumn{2}{|c|}{$\begin{array}{c}\text { Unstandardized } \\
\text { Coefficients }\end{array}$} & $\begin{array}{c}\text { Standardize } \\
\mathrm{d} \\
\text { Coefficients } \\
\end{array}$ & \multirow[b]{2}{*}{$\mathrm{t}$} & \multirow[b]{2}{*}{ Sig. } \\
\hline & $\mathrm{B}$ & Std. Error & Beta & & \\
\hline $\begin{array}{ll}1 & \text { (Consta } \\
& \mathrm{nt})\end{array}$ & .583 & .120 & & 4.875 & .000 \\
\hline SEF & $-6.362 \mathrm{E}-7$ & .000 & -.714 & -.130 & .898 \\
\hline SGEH & $8.224 \mathrm{E}-5$ & .001 & .567 & .103 & .919 \\
\hline
\end{tabular}

a. Dependent Variable: HDI 
